\title{
Retraction to active surveillance of ventilator-associated pneumonia in the intensive care unit and establishment of the risk grading system and effect evaluation
}

doi: $10.21037 /$ atm-2021-1

View this article at: http://dx.doi.org/10.21037/atm-2021-1

Retraction to: Ann Transl Med 2019;7:617

The article entitled "Active surveillance of ventilator-associated pneumonia in the intensive care unit and establishment of the risk grading system and effect evaluation", published in the issue 22, Vol. 7 of Annals of Translational Medicine (1) is being retracted on the ground of plagiarism of the article titled "Risk scoring system for ventilator-associated pneumonia in patients with mechanical ventilation in ICU" published in the issue 20, Vol. 28 of Chinese fournal of Nosocomiology (2). The editors and publisher have confirmed the retraction of this paper.

Open Access Statement: This is an Open Access article distributed in accordance with the Creative Commons AttributionNonCommercial-NoDerivs 4.0 International License (CC BY-NC-ND 4.0), which permits the non-commercial replication and distribution of the article with the strict proviso that no changes or edits are made and the original work is properly cited (including links to both the formal publication through the relevant DOI and the license). See: https://creativecommons.org/ licenses/by-nc-nd/4.0/.

\section{References}

1. Liu W, Jiao Y, Xing H, et al. Active surveillance of ventilator-associated pneumonia in the intensive care unit and establishment of the risk grading system and effect evaluation. Ann Transl Med 2019;7:617.

2. Zhang L, Zhang L, Dai Y, et al. Risk scoring system for ventilator-asociated pneumoniain patients with mechanical ventilation in ICU. Chin J Nosocomiol 2018;28:104-8.

Cite this article as: Retraction to active surveillance of ventilator-associated pneumonia in the intensive care unit and establishment of the risk grading system and effect evaluation. Ann Transl Med 2021;9(3):274. doi: 10.21037/atm-2021-1 